\title{
Changes in the phenylalanine ammonia lyase activity, total phenolic compounds, and flavonoids in Prosopis glandulosa treated with cadmium and copper
}

\author{
DANIEL GONZÁLEZ-MENDOZA ${ }^{1}$, ROSALBA TRONCOSO-ROJAS ${ }^{2}$, TANIA \\ GONZALEZ-SOTO ${ }^{2}$, ONECIMO GRIMALDO-JUAREZ ${ }^{1}$, CARLOS CECEÑA-DURAN ${ }^{1}$, \\ DAGOBERTO DURAN-HERNANDEZ ${ }^{1}$ and FEDERICO GUTIERREZ-MICELI ${ }^{3}$ \\ ${ }^{1}$ Instituto de Ciencias Agrícolas, Universidad Autónoma de Baja California/ICA-UABC, Carretera \\ a Delta, s/n, Casilla Postal 21705, Ejido Nuevo León, Baja California, Mexico \\ ${ }^{2}$ Centro de Investigación en Alimentación y Desarrollo, A.C., Dirección de Tecnología de Alimentos \\ de Origen Vegetal, Carretera a La Victoria, Km 0.6, 83000, Hermosillo, Sonora, Mexico \\ ${ }^{3}$ Tecnológico Nacional de México, Campus Tuxtla Gutiérrez, Carretera \\ Panaméricana, Km 1080, Casilla Postal 29050, Chiapas, Mexico
}

Manuscript received on August 9, 2017; accepted for publication on October 30, 2017

\begin{abstract}
The aim of the present work is to evaluate the changes on the phenylalanine ammonia lyase (PAL) activity, phenolic compounds accumulation and photochemical efficiency in leaves of P. glandulosa treated with $\mathrm{Cd}^{2+}(0.001 \mathrm{M})$ and $\mathrm{Cu}^{2+}(0.52 \mathrm{M})$ concentrations for $96 \mathrm{~h}$ under hydroponic conditions. The results showed that only leaves treated with copper had a decrease in photochemical efficiency and leaf epidermal polyphenols in P. glandulosa leaves after $96 \mathrm{~h}$ of exposure. On the other hand the reverse-phase HPLC analysis revealed higher levels of phenolic compound (gallic, vanillic and caffeic acids) and flavonoids (rutin and kaempferol-3-O-glucosides) in plant leaves from $\mathrm{Cu}$ and $\mathrm{Cd}$-treatments with respect to control plants. Finally, highest increments in PAL activity was observed in extracts of leaves treated with $\mathrm{Cu}$ and Cd (about 205 and 284\%), respectively, with respect to control plants after $96 \mathrm{~h}$ treatment. These suggest that activation of phenylpropanoid pathway represent a source of nonenzymatic antioxidants that protect at $P$. glandulosa against oxidative stress when exposed to cadmium and copper. Hence future studies are necessary to elucidate the participation of phenylpropanoid pathway in the reduction of metal toxicity in Prosopis species.
\end{abstract}

Key words: heavy metals, Prosopis glandulosa, flavonoids, chlorophyll a fluorescence.

\section{INTRODUCTION}

As a result of a rapid industrialization and urbanization processes in the northwest of Mexico, the release of several contaminants like heavy metals in the ecosystem has increased and became

Correspondence to: Daniel González-Mendoza

E-mail: daniasaf@gmail.com a serious problem in these ecoregion of Mexico (Páez-Osuna et al. 2015, Galindo et al. 2010). The heavy metals cause bioaccumulation affecting the entire ecosystem and pose harmful health consequences in all life forms. In the plants, these elements can interfere with different physiological and biochemical processes of the plant system (Sethy and Ghosh 2013). The presence of copper 
and cadmium in the environment generate negative effects in human health due to its high potential to enter and accumulate in the food chain (Pena et al. 2011, Tchounwouetal.2012). Theinadequate supply of both elements results in a variety of changes in plants like inactivation of photosynthesis, formation of free radical and reactive oxygen species, which result in an oxidative stress (Gonzalez-Mendoza et al. 2013). In recent years, some reports have shown that genus Prosopis, can be tolerant to essential and not essential metals even before any visible signs of toxicity are shown (Varun et al. 2011). Due to its ecological and commercial importance, Prosopis species has been extensively used in the last few years to study the effects of heavy metals in the environment (Beramendi-Orosco et al. 2013, Buendía-González et al. 2007). Currently different studies suggested that Prosopis species mainly $P$. juliflora, show the presence of a competent metal uptake and accumulation machinery in roots (Senthilkumar et al. 2005, Mokgalaka-Matlala et al. 2008, Usha et al. 2009).

However, even though the physiological and biochemical mechanisms of heavy metal tolerance or inactivation in Prosopis species have been previously studied, the influence of copper and cadmium in the phenylalanine ammonia lyase (PAL) activity and phenolic compounds accumulation in Prosopis glandulosa has been scarcely evaluated. Therefore, the aim of the present work is to evaluate the changes on the phenylalanine ammonia lyase (PAL) activity, phenolic compounds accumulation and photochemical efficiency in leaves of P. glandulosa exposed to cadmium and copper.

\section{MATERIALS AND METHODS}

\section{DISINFECTION OF SEEDS}

One hundred seeds of Prosopis glandulosa was disinfested with $1.5 \% \mathrm{NaOCl}$ for $3 \mathrm{~min}$, followed of a washed with abundant water. Later, the seedlings were cultivated with $12 \mathrm{~h}$ light:dark photoperiods in a greenhouse, $60 \%$ relative air humidity temperature and day/night temperatures a range of $30 / 32{ }^{\circ} \mathrm{C}$ were used. The fertilization of seedlings was according to previous described by Gonzalez-Mendoza et al. (2013).

\section{CADMIUM AND COPPER EXPOSURE}

Twenty-three-days-old $P$. glandulosa seedlings were randomly selected and transferred to individual plastic containers with $250 \mathrm{ml}$ Hoagland's solution prepared with any one of the following heavy metal exposure levels ( $n=10$ per treatment level): (a) $0.001 \mathrm{M}$ cadmium chloride $\left(\mathrm{CdCl}_{2}\right)$ and (b) $0.52 \mathrm{M}$ copper sulfate $\left(\mathrm{CuSO}_{4} \cdot 5 \mathrm{H}_{2} \mathrm{O}\right)$. Control plants were transferred to plastic containers with $250 \mathrm{ml}$ Hoagland's solution without $\mathrm{CdCl}_{2}$ or $\mathrm{CuSO}_{4} \cdot 5 \mathrm{H}_{2} \mathrm{O}$. Treated and control plants were exposed to their respective solutions for $96 \mathrm{~h}$ under hydroponics conditions.

\section{DETERMINATION OF PHYSIOLOGICAL PARAMETERS}

The determination of polyphenol contents (Phen) of the plant leaves were measured on the middle part of the third pair fully expanded leaves using an optical sensor (Dualex Scientific $+{ }^{\mathrm{TM}}$ ) according to (Cartelat et al. 2005). For pigment analysis, the content of polyphenols was expressed as Dualex units. Assessments were realized at 0, 24, 48, 72 and $96 \mathrm{~h}$ after treatment with copper and cadmium. The chlorophyll fluorescence was analyzed with an OS-30p Fluorometer (OPTI-SCIENCE, USA) on completely expanded leaves. Previously, the plant leaves were dark-adapted for $5 \mathrm{~min}$. The potential photochemical yield $(\mathrm{Fv} / \mathrm{Fm})$ was recorded at a saturating actinic light $(660 \mathrm{~nm})$ intensity of 1100 $\mu \mathrm{mol} / \mathrm{m}^{2} / \mathrm{s}$. For each treatment, the $F v / F m$ of ten individual leaves were measured at $0,24,48,72$ and 96 after exposure to heavy metals according to proposed by Gonzalez-Mendoza et al. (2013). 
IDENTIFICATION OF PHENOLIC ACIDS AND FLAVONOIDS BY HPLC

Qualitative and quantitative analyses of phenolic compounds and flavonoids in P. glandulosa samples were done by gradient elution high performance liquid chromatography (HPLC) analysis $96 \mathrm{~h}$ after of exposure to cadmium and copper prepared according to (Cervantes-Garcia et al. 2016). Separation of phenolic acids was carried out by The HPLC system consisted of quaternary pump model 9012, equipped with an UV detector model 9050, a Prodigy 5u ODS3 100A (Phenomenex, CA, USA) column (250 mm length, $4.6 \mathrm{~mm}$ of internal diameter and $5 \mu \mathrm{m}$ particle size) with a C-18 guard column. The detector was set to $280 \mathrm{~nm}$ and flow rate to $1 \mathrm{ml} / \mathrm{min}$ (Varian Inc., Co. Palo Alto, CA, USA). The solutions of the phenolic acid mixture were prepared with $0.01 \mathrm{~g}$ of each phenolic acid and mixed with a solution of 1:1 ammonium acetate buffer $200 \mathrm{~mm} \mathrm{pH} 5.4$ and methanol.

The efficiency of the HPLC methodology for separation of phenolic acids and flavonoids was tested by preparing a solution containing the following commercially available standards: gallic acid, protocatechuic acid, hydroxybenzoic acid, vanillic acid, chlorogenic acid, caffeic acid, ferulic acid, $p$-coumaric acid, sinapic acid, $o$-coumaric acid, naringenin, kaempferol, quercetin, rutin, naringin and cinnamic acid (Sigma-Aldrich Chemical Co. St. Louis, MO, USA).

PHENYLALANINE AMMONIA-LYASE (PAL) ACTIVITY ASSAY

To assess PAL activity, $2 \mathrm{~g}$ of leaves tissues of $P$. glandulosa were homogenized in $5 \mathrm{~mL}$ of Tris-HCl buffer $(0.1 \mathrm{M}, \mathrm{pH} 7.5)$ containing $1 \%$ polyvinylpolypyrrolidone and EDTA $(1 \mathrm{mM})$ after $96 \mathrm{~h}$ of exposure to heavy metals. The homogenate was centrifuged at $12,000 \mathrm{rpm}$, at $4{ }^{\circ} \mathrm{C}$ for $10 \mathrm{~min}$ and was tested for PAL activity according to Cindi et al. (2016) by measuring the absorbance of transcinnamic acid at $290 \mathrm{~nm}$ with some modifications. The reaction mixture contained the enzyme extract $(100 \mu \mathrm{L}), 200 \mu \mathrm{L}$ of Tris-HCl (50 mM, pH 8.8) containing $20 \mathrm{mM}$ L-phenylalanine and incubated for $30 \mathrm{~min}$ at $40{ }^{\circ} \mathrm{C}$. After incubation time the reaction was stopped by the addition of $100 \mu \mathrm{L}$ of $1 \mathrm{M} \mathrm{HCl}$ and the production of cinnamate was measured at $290 \mathrm{~nm}$. One unit of the enzyme was defined as increase in absorbance of one unit per min. The activity of the enzyme was expressed as units per mg of soluble protein.

\section{STATISTICAL ANALYSIS}

Differences between the treatments were evaluated using one-way analyses of variance and the Tukey's test $(P £ 0.05)$, and SAS Version 9.0 (SAS Institute, 2002) was used.

\section{RESULTS}

EPIDERMAL POLYPHENOLS (Ephen) AND CHLOROPHYLL A FLUORESCENCE

The content of EPhen in control P. glandulosa leaf did not show any changes during the experiment (Fig. 1). However, when this species was exposed to a copper solution showed a decreased after $48 \mathrm{~h}$ of exposure to metal (Fig. 1). In contrast the EPhen in the $P$. glandulosa leaf exposed to cadmium did not exhibit significantly changes compared with the plants treated only with water (Fig. 1). The measurements of chlorophyll a fluorescence showed a significantly decrease $(P<0.05)$ on photochemical efficiency $(F v / F m)$ value of $P$. glandulosa treated with copper dose from 48 hours followed by a dropped of $48 \%$ after $96 \mathrm{~h}$ of exposure with respect to control (Fig. 2). Finally, $\mathrm{Fv} / \mathrm{Fm}$ values observed in leaf of $P$. glandulosa treated with cadmium did not show significantly changes with respect to control (Fig. 2). 


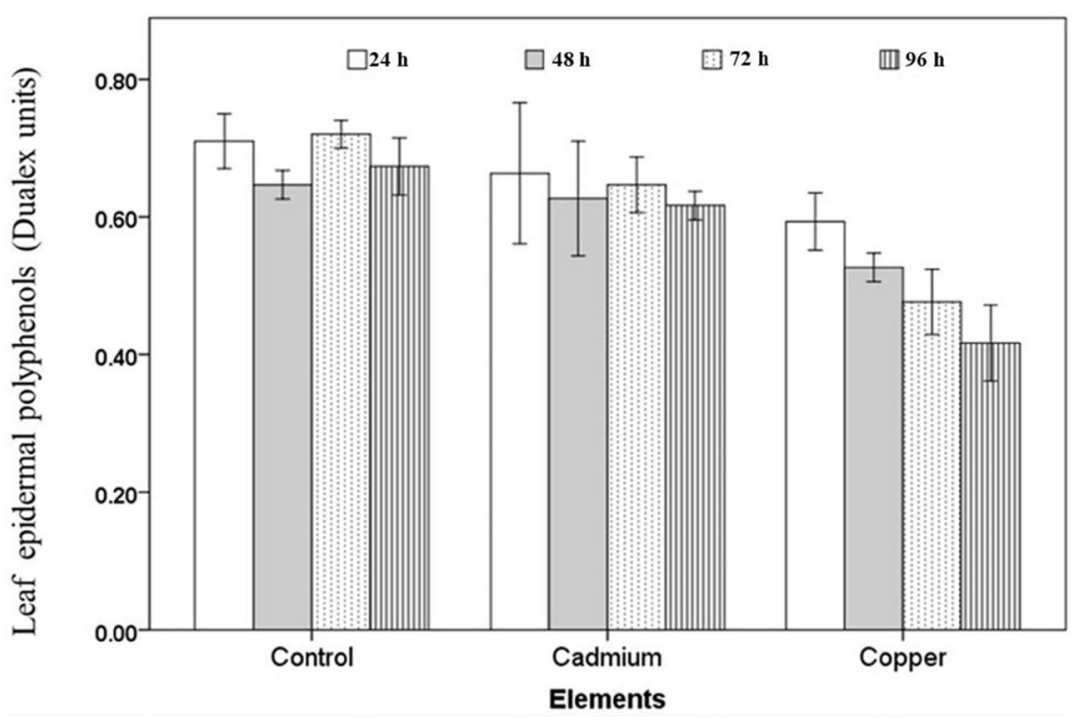

Figure 1 - Time course repsonse of epidermal polyphenols (Dualex units) in leaves of $P$. glandulosa exposed to copper and cadmium after $96 \mathrm{~h}$ of treatment. Means \pm Standard error. $n=4$.

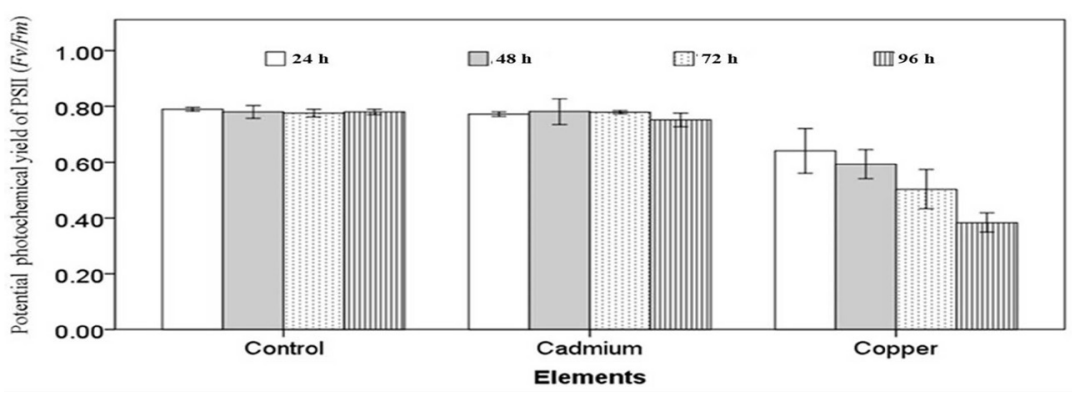

Figure 2 - Time course response of potential photochemical yield of PSII $(\mathrm{Fv} / \mathrm{Fm})$ measured in leaves of $P$. glandulosa exposed to copper and cadmium after $96 \mathrm{~h}$ of treatment. Means \pm Standard error. $n=4$.

\section{IDENTIFICATION OF PHENOLIC ACIDS AND FLAVONOIDS BY HPLC}

In the present study, seven individual phenolic compounds (gallic acid, hydroxybenzoic acid, chlorogenic acid, caffeic acid, vanillic acid, $p$-coumaric acid and ferulic acid) were analyzed and quantified using reverse-phase HPLC for all the plant treatments of $P$. glandulosa after $96 \mathrm{~h}$ of exposure (Fig. 3). Our result showed that $\mathrm{Cd}$ exposure increased gallic (10.5 \pm 0.008$)$, vanillic $(3.14 \pm 0.14)$ and caffeic acids $(1.42 \pm 0.2)$, in $P$. glandulosa leaves when compared to the control treatment (Fig. 4). Also, there was a significant decrease in the concentrations of hydroxybenzoic acid (5.27 \pm 0.5$), p$-coumaric acid (10.91 \pm 0.29$)$ and ferulic acid $(1.35 \pm 0.12)$ in leaves treated with Cd (Fig. 4). In contrast, our study revealed that plants treated with $\mathrm{Cu}$, increased only caffeic acid (2.7 \pm 0.02$)$ in $P$. glandulosa leaves when compared to the control group after $96 \mathrm{~h}$ of treated (Fig. 4).

On the other hand, individual flavonoids compounds like naringenin, rutin, quercetin, kaempferol, kaempferol-3-O-rutinoside, kaempferol-3-O-glucoside and naringeninchalcone were detected using reverse-phase HPLC 


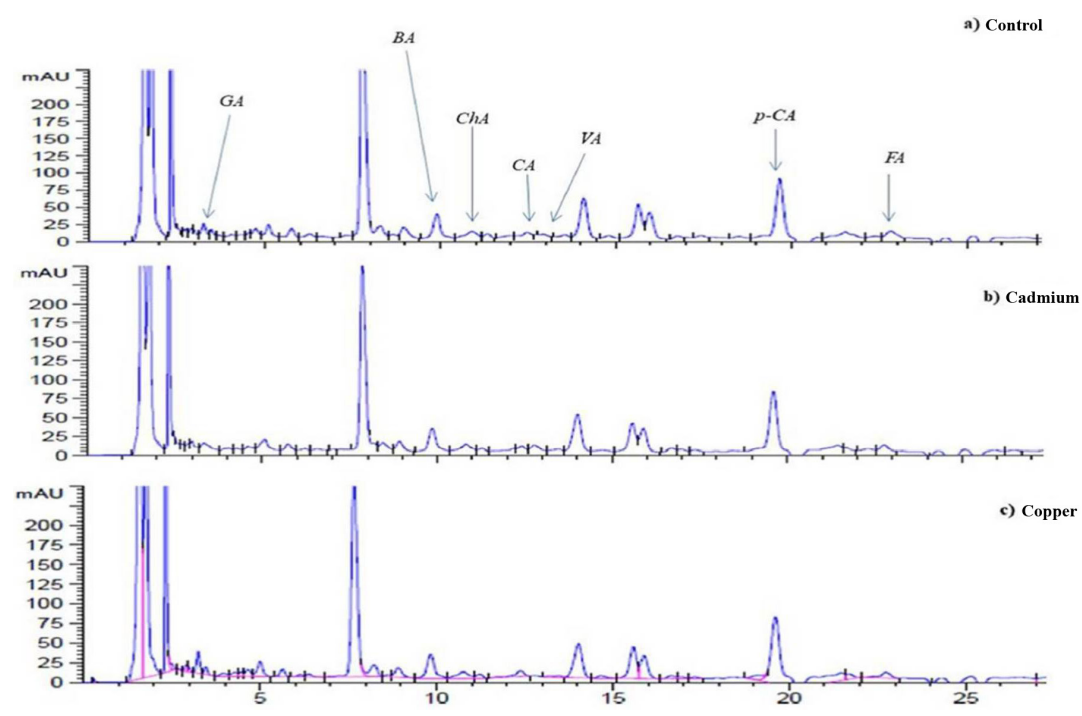

Figure 3 - Differences in phenolic compounds of hydrolysed extracts of Prosopis glandulosa: (a) control, (b) Cadmium (0.001 M) and (c) Copper (0.52 M) Peaks: GA, gallic acid; $B A$, hydroxybenzoic acid; $C h A$, chlorogenic acid; $C A$, caffeic acid; $V A$, vanillic acid; $p C A, p$-coumaric acid; $F A$, ferulic acid acid.

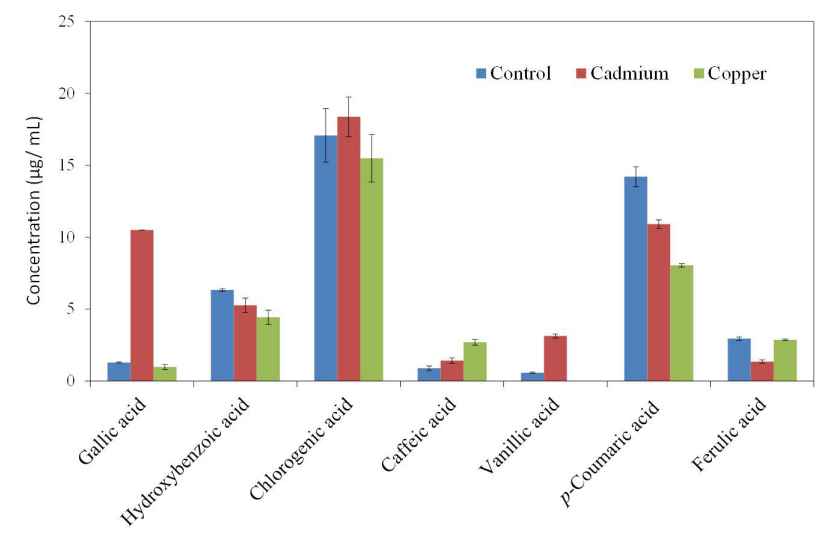

Figure 4 - Concentration of phenolic compounds of hydrolysed extracts of Prosopis glandulosa treated with Cadmium (0.001 $\mathrm{M})$ and Copper $(0.52 \mathrm{M})$. Means \pm Standard error. $n=4$.

for all the treatments of $P$. glandulosa after $96 \mathrm{~h}$ of exposure (Fig. 5). In the present study rutin and kaempferol-3-O-glucoside were present most abundantly in extracts of leaves from $\mathrm{Cu}$ and $\mathrm{Cd}$ treatments with respect to control plants (Fig. 5). However, only Cd-treatment increased narigenin (2.65 \pm 0.18$)$ and kaempferol-3-O-rutinoside (3.14 $\pm 0.14)$ in $P$. glandulosa leaves when compared to the control treatment. In contrast, the highest amount of naringenin-chalcone was found in $\mathrm{Cu}$-treatment of leaf whereas minimum in Cd-treatment (Fig. 6). Finally, quercetin was significantly reduced in the leaves of all treatments with heavy metals but not in control plants (Fig. 6).

\section{PHENYLALANINE AMMONIA-LYASE (PAL) ACTIVITY ASSAY}

Our results showed changes in PAL activity of $P$. glandulosa treated with copper and cadmium after 96 h of exposure are shown in Figure 6. Highest 


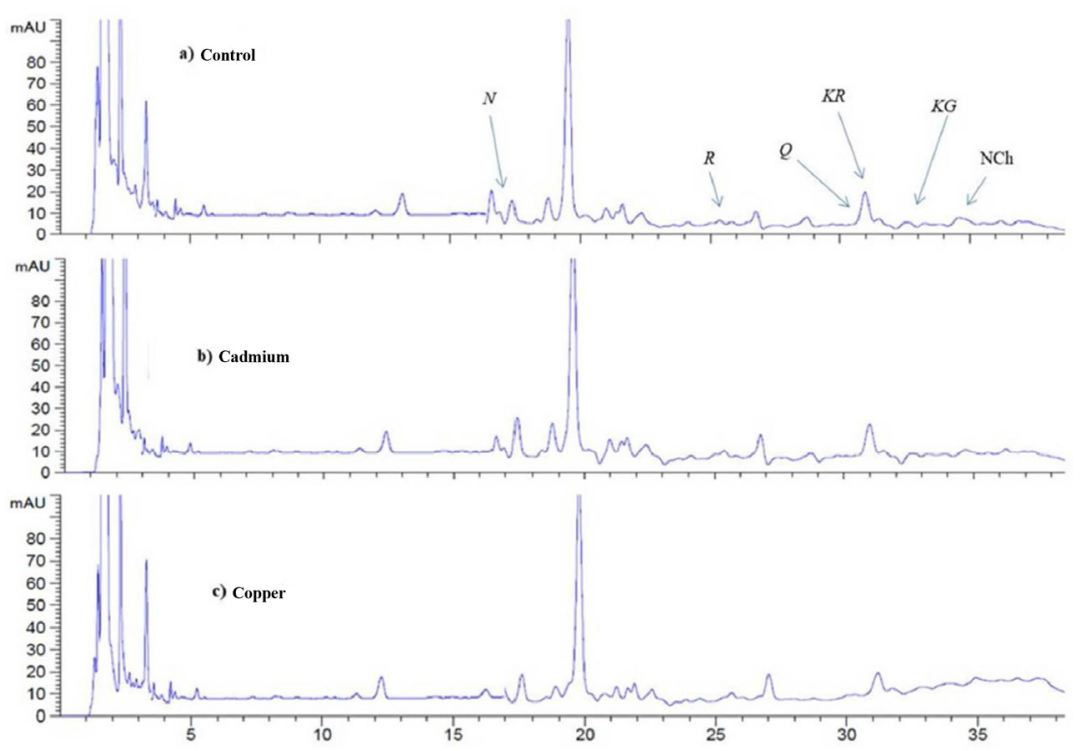

Figure 5 - Differences in flavonoid compounds of hydrolysed extracts of Prosopis glandulosa: (a) control, (b) Cadmium (0.001 M) and (c) Copper (0.52 M). Peaks: $N$, narigenin; $R$, rutin, $Q$, quercetin; $K$, kaempferol; $K R$, kaempferol-3-O-rutinoside; $K G$, kaempferol-3-O-glucoside; and $N C h$, naringenin-chalcone.

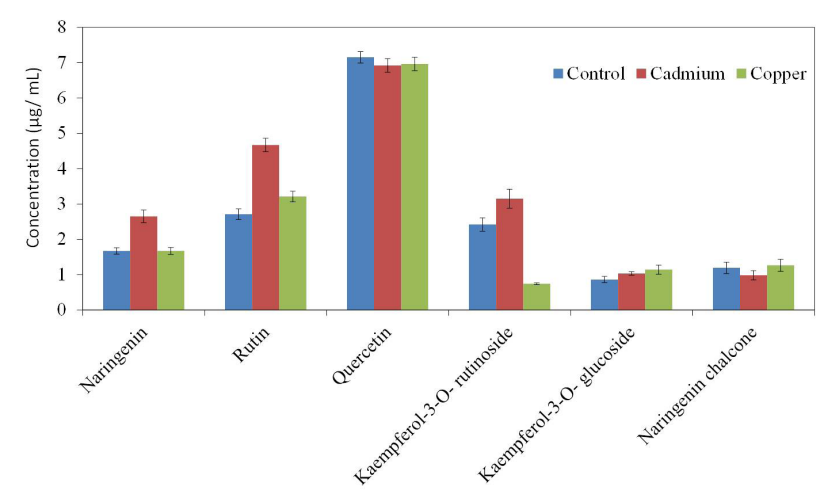

Figure 6 - Concentration of flavonoids of hydrolysed extracts of Prosopis glandulosa treated with Cadmium $(0.001 \mathrm{M})$ and Copper (0.52 M). Means \pm Standard error. $n=4$.

increments in PAL activity was observed in extracts of leaves treated with $\mathrm{Cu}$ and $\mathrm{Cd}$ (about 205 and $284 \%$ ), respectively, with respect to control plants (Table I).

\section{DISCUSSION}

Recent studies have suggested that the epidermal polyphenols (EPhen) content in plants, mainly flavonoids, may act as chelate agents of metal ions reducing the presence of free radicals, and protect against oxidative stress (Mierziak et al. 2014). In the present study our results showed that the synthesis of EPhen was negatively affected when $P$. glandulosa was treated with copper. The low values of EPhen observed could be explained by impairment of antioxidative system due to the exposure to copper reducing the synthesis of new polyphenols. 
TABLE I

Assessment of the activity of phenylalanine ammonia lyase (PAL) in Prosopis glandulosa after $96 \mathrm{~h}$ exposure to heavy metals.

\begin{tabular}{cc}
\hline Treatments & $\begin{array}{c}\text { PAL (units/mg soluble } \\
\text { protein) }\end{array}$ \\
\hline P. glandulosa control & $73.11 \pm 2.79^{\mathrm{a}}$ \\
P. glandulosa-Cadmium & $207.73 \pm 0.64^{\mathrm{b}}$ \\
P. glandulosa-Copper & $150.28 \pm 8.71^{\mathrm{c}}$ \\
\hline
\end{tabular}

Data are means \pm S.D. $(n=4)$. Those with different superscrip letter $(\mathrm{a}, \mathrm{b}$, and $\mathrm{c})$ in the same column are significantly different $(P<0.05$, tukey multiple comparison).

Thus as a results of cooperation of EPhen with different antioxidant metabolites to scavenge the hydrogen peroxide which leaks out from mesophyll cells where it is produced in response to heavy metals such as copper (Sakihama et al. 2002, Mierziak et al. 2014). Surprisingly, no effects were observed when $P$. glandulosa was exposed to cadmium. This response to this metal may be the result of the presence of biochemistry strategies such as synthesis of metallothioneins which help in the reduction of stress caused by cadmium in different plants (Gonzalez-Mendoza et al. 2007, Gonzalez-Mendoza and Zapata-Perez 2008). On the other hand, the lack of increase in phenolic and flavonoid compounds in P. glandulosa exposed to $0.001 \mathrm{M} \mathrm{Cd}^{+2}$ could be attributed to the impairment of antioxidative system responses due to the exposure to a high concentration of this metal, in such a way that this organism is not able to synthesize new phenolic and flavonoid compounds. Similar results has been reported in Euglena gracilis, which is not able to counteract the effects of exposure to high concentration of $\mathrm{Cd}^{+2}$ (Cervantes-Garcia et al. 2016). Recent studies has reported that flavonoid and phenolic compounds could act as alternative antioxidants when antioxidative enzymes are affect by heavy metals (Márquez-García et al. 2009). In this sense our results showed that copper and cadmium stimulates the activity of PAL in P. glandulosa leaves. This suggest that PAL activation and increased of phenolics and flavonoids compounds can act as source of nonenzymatic antioxidants and protect $P$. glandulosa from oxidative stress when exposed to heavy metals $(\mathrm{Cd}$ and $\mathrm{Cu})$. These results are in agreement with previous studies reported by Pawlak-Sprada et al. (2011), that suggest antioxidant and metal chelating properties of phenolic and flavonoid compounds in plants exposed to heavy metals.

Additionality, our results showed that the reduction in $F v / F m$ values observed in P. glandulosa could be explained by negative effects of copper on the structure and composition of reaction center complex (RC) of photosystem II reaction centers (Gonzalez-Mendoza et al. 2013). Nevertheless, the differences in the $\mathrm{Fv} / \mathrm{Fm}$ values among $\mathrm{Cd}^{+2}$ and $\mathrm{Cu}^{+2}$ may be related to their capacity of acquisition and transport by P. glandulosa leaves. For example, previous studies showed the presence low values of cadmium-transportation index in Prosopis juliflora suggesting the participation of exclusion processes that regulate the metals uptake in leaves (Michel-López et al. 2016). Finally, according to our research, high production of phenolic and flavonoid compounds in plants of $P$. glandulosa under the cadmium and copper influence during the experiment are consistent with a significant increase in the PAL activity. This suggests that activation of phenylpropanoid pathway represent asource of nonenzymatic antioxidants that protect at $P$. glandulosa against oxidative stress when exposed to heavy metals. The decreased quercetin and hydroxybenzoic acid, $p$-coumaric acid and ferulic acid accumulation in $P$. glandulosa leaves in response to heavy metals, despite an increased PAL activity, suggests that the activated phenylpropanoid pathway was involved in the synthesis of secondary metabolites other than phenolics compounds. Hence future studies are necessary to elucidate the participation of phenylpropanoid pathway in the reduction of metal toxicity in Prosopis species. 


\section{ACKNOWLEDGMENTS}

The authors are particularly gratefully to Conacyt Ciencia Basica 2013 (\# 219750).

\section{REFERENCES}

BERAMENDI-OROSCO LE, RODRIGUEZ-ESTRADA ML, MORTON-BERMEA O, ROMEO FM, GONZALEZHERNANDEZ G AND HERNANDEZ-ALVAREZ E. 2013. Correlations between metals in tree-rings of Prosopis juliflora as indicators of sources of heavy metal contamination. Appl Geochem 39: 78-84.

BUENDÍA-GONZÁLEZ L, OROZCO-VILLAFUERTE J, CRUZ-SOSA F, CHÁVEZ-ÁVILA VM AND VERNONCARTER EJ. 2007. Clonal propagation of mesquite tree (Prosopis laevigata Humb. \& Bonpl. ex Willd. M.C. Johnston).I. Via cotyledonary nodes. In Vitro Cell Dev Biol Plant 43: 260-266.

CARTELAT A ET AL. 2005. Optically assessed contents of leaf polyphenolics and chlorophyll as indicators of nitrogen deficiency in wheat (Triticum aestivum L.) Field Crops Res 91: 35-49.

CERVANTES-GARCIA D, TRONCOSO-ROJAS R, SÁNCHEZ-ESTRADA A, GONZALEZ-MENDOZA D, GUTIERREZ-MICELI F, CECEÑA-DURAN C AND GRIMALDO-JUAREZ O. 2016. Effects of cadmium on total phenolic compounds and flavonoids in Euglena gracilis. Gayana 80: 1-5.

CINDI MD, SOUNDY P, ROMANAZZI G AND SIVAKUMAR D. 2016. Different defense responses and brown rot control in two Prunus persica cultivars to essential oil vapours after storage. Postharvest Biol Technol 119: 9-17.

GALINDO EAG, BARBOSA AM, VELASCO MRM, DAESSLÉ LW AND OROZCO BORBÓN MV. 2010. Distribution and Enrichment of Silver and Cadmium in Coastal Sediments from Bahia Todos os Santos, Baja California, Mexico. Bull Environ ContamToxicol 85: 391396.

GONZALEZ-MENDOZA D, FRANCISCO ESPADAS G, ESCOBOZA-GARCIA F, SANTAMARIA JM AND ZAPATA-PEREZ O. 2013. Copper Stress on Photosynthesis of Black Mangle (Avicennia germinans). An Acad Bras Cienc 85: 665-670.

GONZALEZ-MENDOZA D, MORENO AQ AND ZAPATAPEREZ O. 2007. Coordinated responses of phytochelatin synthase and metallothionein genes in black mangrove, Avicennia germinans, exposed to cadmium and copper. Aquat Toxicol 83: 306-314.

GONZALEZ-MENDOZA D AND ZAPATA-PEREZ O. 2008. Mecanismos de tolerancia a elementos potencialmente tóxicos en plantas. Bol Soc Bot México 82: 53-61

MÁRQUEZ-GARCÍA B, FERNÁNDEZ MA AND CÓRDOBA F. 2009. Phenolics composition in Erica sp. differentially exposed to metal pollution in the Iberian southwestern Pyritic Belt. Bioresour Bioprocess 100: 446451.

MICHEL-LÓPEZ C, ESPADA-GIL F, FUENTES-ORTIZ G, SANTAMARIA JM, GONZALEZ-MENDOZA D, CECEÑA-DURAN C AND GRIMALDO-JUAREZ O. 2016. Bioaccumulation and effect of cadmium in the photosynthetic apparatus of Prosopis juliflora. Chemical Speciation and Bioavailability 28: 1-4.

MIERZIAK J, KOSTYN K AND KULMA A. 2014. Flavonoids as Important Molecules of Plant Interactions with the Environment. Molecules 19: 16240-16265

MOKGALAKA-MATLALA NS, FLORES-TAVIZÓN E, CASTILLO-MICHEL H, PERALTA-VIDEA JR AND GARDEA-TORRESDEY JL. 2008. Toxicity of arsenic (III) and (V) on plant growth, element uptake, and total amylolytic activity of mesquite (Prosopis juliflora $\mathrm{x} P$. velutina). Int J Phytoremediation 10: 47-60.

PÁEZ-OSUNA F, BOJÓRQUEZ-LEYVA H, BERGÉSTIZNADO M, RUBIO-HERNÁNDEZ OA, FIERROSAÑUDO JF, RAMÍREZ-ROCHÍN J AND LEÓNCAÑEDO JA. 2015. Heavy metals in waters and suspended sediments affected by a mine tailing spill in the upper San Lorenzo River, Northwestern Mexico. Bull Environ Contam Toxicol 94: 583-588.

PAWLAK-SPRADA S, ARASIMOWICZ-JELONEK M, PODGÓRSKA M AND DECKERT J. 2011. Activation of phenylpropanoid pathway in legume plants exposed to heavy metals. Part I. Effects of cadmium and lead on phenylalanine ammonia-lyase gene expression, enzyme activity and lignin content. Acta Biochim Pol 58: 211 216.

PENA LB, AZPILICUETA CE AND GALLEGO SM. 2011. Sunflower cotyledons cope with copper stress by inducing catalase subunits less sensitive to oxidation. J Trace Elem Med Biol 25: 125-129.

SAKIHAMA Y, COHEN MF, GRACE SC AND YAMASAKI H. 2002. Plant phenolic antioxidant and prooxidant activities: phenolics-induced oxidative damage mediated by metals in plants. Toxicology 177: 67-80.

SENTHILKUMAR P, PRINCE W, SIVAKUMAR S AND SUBBHURAAM CV. 2005. Prosopis juliflora - A green solution to decontaminate heavy metal $(\mathrm{Cu}$ and $\mathrm{Cd})$ contaminated soils. Chemosphere 60: 1493-1496.

SETHY SK AND GHOSH S. 2013. Effect of heavy metals on germination of seeds. J Nat Sc Biol Med 4: 272-275.

TCHOUNWOU PB, YEDJOU CG, PATLOLLA AK AND SUTTON DJ. 2012. Heavy Metals Toxicity and the Environment. EXS 101: 133-164.

USHA B, VENKATARAMAN G AND PARIDA A. 2009. Heavy metal and abiotic stress inducible metallothionein isoforms from Prosopis juliflora (SW) DC show differences in binding to heavy metals in vitro. Mol Genet Genomics 281: 99-108.

VARUN M, D'SOUZA R, PRATAS J AND PAUL MS. 2011. Phytoextraction potential of Prosopis juliflora (Sw.) DC. with specific reference to lead and cadmium. Bull Environ Contam Toxicol 87: 45-49. 